\title{
Penerapan Model Pembelajaran Problem Based Learning (PBL) untuk Meningkatkan Aktivitas dan Hasil Belajar PPKn pada Materi Kewenangan Lembaga-Lembaga Negara
}

\author{
I Nyoman Gede Brathatapa ${ }^{1 *}$
}

${ }^{1}$ SMK Negeri 2 Negara, Jembrana, Indonesia

\author{
A R T I C L E I N F O \\ Article history: \\ Received 10 February \\ 2021 \\ Received in revised form \\ 25 March 2021 \\ Accepted 10 April 2021 \\ Available online 11 May \\ 2021 \\ Kata Kunci: \\ PBL, PPKn, Aktivitas, Hasil \\ Belajar \\ Keywords: \\ Speaking Skill, Three Step \\ Interview.
}

\begin{abstract}
A B S T R A K
Penggunaan model pembelajaran yang tidak tepat dapat menyebabkan rendahnya aktivitas dan hasil belajar siswa khususnya pada muatan pelajaran PPKn, sehingga diperlukan model pembelajaran dapat memotivasi siswa untuk belajar. Penelitian ini bertujuan untuk menganalisis penerapan model pembelajaran $P B L$ terhadap aktivitas dan hasil belajar PPKn siswa. Penelitian ini merupakan termasuk jenis penelitian tindakan kelas (PTK). Subjek penelitian ini semua siswa kelas $X$ dan objek dari penelitian ini adalah peningkatan aktivitas belajar dan hasil belajar siswa. Teknik pengumpulan data yang digunakan pada penelitian ini adalah observasi dan tes hasil belajar. Untuk memperoleh persentase aktivitas dan hasil belajar siswa, teknik analisis data yang yang digunakan adalah teknik analisis statistik deskriptif kuantitatif. Berdasarkan hasil penelitian diperoleh persentase aktivitas siswa pada pra siklus sebesar $44,44 \%$, siklus 1 sebesar $62,72 \%$ dan siklus 2 sebesar $87,46 \%$, sedangkan hasil belajar siswa pra siklus sebesar $29.03 \%$, siklus I sebesar $74.19 \%$, dan siklus II sebesar $93.55 \%$.
\end{abstract} Simpulan penelitian ini adalah penerapan model pembelajaran $P B L$ terbukti dapat meningkatkan aktivitas dan hasil belajar PPKn siswa. Implikasi dari penelitian ini adalah penerapan model pembelajaran $P B L$ dapat memotivasi siswa untuk belajar dan menambah pengalaman baru bagi siswa.

\begin{abstract}
A B S T R A K
The use of learning models that are not appropriate can lead to low activity and student learning outcomes, especially in the PPKn lesson content, so that a learning model is needed to motivate students to learn. This study aims to analyze the application of the PBL learning model to students' PPKn learning activities and outcomes. This research is a type of classroom action research (PTK). The subjects of this study were all students of class $X$ and the object of this study was the improvement of learning activities and student learning outcomes. Data collection techniques used in this study were observation and learning outcomes tests. To obtain the percentage of student activity and learning outcomes, the data analysis technique used is descriptive quantitative statistical analysis techniques. Based on the research results, the percentage of student activity in the pre-cycle was $44.44 \%$, cycle 1 was $62.72 \%$ and cycle 2 was $87.46 \%$, while the pre-cycle student learning outcomes were $29.03 \%$, cycle I was $74.19 \%$, and cycle II amounting to $93.55 \%$. The conclusion of this research is that the application of the PBL learning model is proven to increase the activities and learning outcomes of students' PPKn. The implication of this research is that the application of the PBL learning model can motivate students to learn and add new experiences for students.
\end{abstract}

\section{Pendahuluan}

Pendidikan dan pengajaran adalah suatu proses yang sadar tujuan. Tujuan dapat diartikan sebagai suatu usaha untuk memberikan rumusan hasil yang diharapkan siswa setelah melaksanakan pengalaman belajar (Amelia \& Saputra, 2017; Kurniaman \& Noviana, 2017; Wahyudin, 2018). Tercapai 
tidaknya tujuan pengajaran salah satunya adalah terlihat dari prestasi belajar yang diraih siswa. Dengan prestasi yang tinggi, para siswa mempunyai indikasi berpengetahuan yang baik. Salah satu faktor yang mempengaruhi prestasi siswa adalah motivasi. Dengan adanya motivasi, siswa akan belajar lebih keras, ulet, tekun dan memiliki dan memiliki konsentrasi penuh dalam proses belajar pembelajaran. Dorongan motivasi dalam belajar merupakan salah satu hal yang perlu dibangkitkan dalam upaya pembelajaran di sekolah.

Teori pendidikan merupakan landasan dan pijakan awal dalam pengembangan praktik pendidikan, misalnya pengembangan kurikulum, manajemen sekolah dan proses belajar mengajar. Kurikulum dan pembelajaran memiliki keterkaitan dengan teori pendidikan atau dalam penyusunan suatu kurikulum dan rencana pembelajaran ini mengacu pada teori pendidikan (Indriani, 2015; Krissandi \& Rusmawan, 2015; Nuryana \& Sahrir, 2020). Salah satu muatan pembelajaran yang dapat diajarkan di sekolah yaitu PPKn.

Mata pelajaran PPKn berperan untuk pengembangan intelektual, sosial, emosional siswa dan berperan sebagai kunci penentu menuju keberhasilan dalam mempelajari suatu bidang tertentu (Larasati \& Gafur, 2018; Mediatati, 2017; Sanistyasari, 2019). Di samping mengetahui peran mata pelajaran PPKn, sebagai seorang guru juga diperlukan untuk mampu menerapkan beberapa metode ajar sehingga paradigma pengajaran dapat dirubah menjadi paradigma pembelajaran student centered.

Berdasarkan hasil observasi SMK Negeri 2 Negara, kejadian yang sering terjadi selama proses pembelajaran yang dilakukan selama ini yang menyebabkan rendahnya aktivitas dan hasil belajar siswa tidak sepenuhnya disebabkan oleh faktor luar seperti kesibukan guru, keadaan rumah tangga, lingkungan dan lain-lain. Kelemahan-kelemahan yang ada tentu banyak pula dipengaruhi oleh faktor dari dalam guru itu sendiri seperti kemauan menyiapkan bahan yang lebih baik, kemauan guru itu sendiri untuk menerapkan metode-metode ajar yang telah didapat di bangku kuliah. Selain itu guru juga kurang mampu untuk dapat mengembangkan keterampilan mengajar yang dapat menarik perhatian siswa dan merangsang siswa untuk belajar. Keterampilan yang mesti dikuasai guru dalam melaksanakan pembelajaran ada 7, yaitu: (1) keterampilan bertanya; (2) keterampilan memberi penguatan, 3) keterampilan mengadakan variasi, 4) keterampilan menjelaskan; (5) keterampilan membuka dan menutup pelajaran; (6) keterampilan membimbing diskusi; (7) keterampilan mengelola kelas (Khofiatun et al., 2016; Larasati \& Gafur, 2018; Maiza \& Nurhafizah, 2019). Melihat kesenjangan antara harapanharapan yang telah disampaikan dengan kenyataan lapangan sangat jauh berbeda, dalam upaya memperbaiki mutu pendidikan utamanya pada mata pelajaran matematika sangat perlu kiranya dilakukan perbaikan cara pembelajaran. Salah satunya adalah perbaikan pembelajaran dengan menggunakan model pembelajaran Problem Based Learning (PBL).

Model sangat berkaitan dengan teori, model merupakan suatu analog konseptual yang digunakan untuk menyarankan bagaimana meneruskan penelitian empiris sebaiknya tentang suatu masalah. Jadi model merupakan suatu struktur konseptual yang telah berhasil dikembangkan dalam suatu bidang dan sekarang diterapkan, terutama untuk membimbing penelitian dan berpikir dalam bidang lain, biasanya dalam bidang yang belum begitu berkembang (Istiandaru et al., 2015; Juliawan et al., 2017; Wajdi, 2017).

Model pembelajaran merupakan kerangka konseptual yang melukiskan prosedur yang sistematis dalam mengorganisasi pengalaman belajar untuk mencapai tingkat belajar tertentu. (Farah et al., 2020; Maryatun \& Metro, 2017; Rerung et al., 2017) menjelaskan bahwa model pembelajaran merupakan suatu rencana atau pola yang digunakan untuk membentuk kurikulum, merancang bahan pengajaran dan membimbing pengajaran di kelas. Dari pendapat tersebut di atas dapat disimpulkan bahwa model pembelajaran merupakan kerangka konseptual dalam wujud suatu perencanaan pembelajaran yang melukiskan prosedur yang sistematis yang digunakan sebagai pedoman dalam pembelajaran di kelas. Istilah model pembelajaran mempunyai empat ciri khusus yakni: (1) rasional teoretik yang logis yang disusun oleh para pencipta; (2) landasan pemikiran tentang apa dan bagaimana siswa belajar (3) tingkah laku mengajar yang diperlukan agar model tersebut dapat berhasil; (4) lingkungan belajar yang diperlukan agar tujuan pembelajaran itu dapat tercapai (Han \& Rosli, 2016; Herzon et al., 2018; Ramlawati et al., 2017).

Sintaks suatu model pembelajaran menggambarkan keseluruhan urutan alur langkah yang pada umumnya diikuti oleh serangkaian kegiatan pembelajaran (Alkhasawneh et al., 2008; Ratnawati et al., 2020; Sumarni et al., 2016). Sintaks pembelajaran menunjukkan dengan jelas kegiatan-kegiatan apa yang perlu dilakukan oleh guru atau siswa dan tugas-tugas khusus yang dilakukan oleh siswa. Model-model pembelajaran juga merupakan hal yang sangat penting dalam penerapannya di lapangan, seperti model Problem Based Learning (PBL) yang dijadikan objek penelitian sebagai upaya untuk memajukan suatu bidang tertentu.

Model pembelajaran problem based learning (pembelajaran berbasis masalah), awalnya dirancang untuk program graduate bidang kesehatan oleh Barrows, Howard yang kemudian diadaptasi 
dalam bidang pendidikan oleh Gallagher (Fitri et al., 2020; Ratnawati et al., 2020; Tomas \& Prasetyo, 2020). Kelebihan model pemblajaran problem based learning (PBL) disetting dalam bentuk pembelajaran yang diawali dengan sebuah masalah dengan menggunakan instruktur sebagai pelatihan metakognitif dan diakhiri dengan penyajian dan analisis kerja siswa, dengan aktivitas tersebut dapat memotivasi siswa untuk mengikuti kegiatan pembelajaran dengan baik (Pratiwi \& Setyaningtyas, 2020; Sucipto, 2017; Suhendar \& Ekayanti, 2018).

Proses belajar merupakan proses yang dialami secara langsung dan aktif oleh pelajar pada saat mengikuti suatu kegiatan belajar mengajar yang direncanakan atau disajikan di sekolah, baik yang terjadi di kelas maupun di luar kelas (Abdurrozak \& Jayadinata, 2016; Ariyanti, 2017; Christiana et al., 2014). Dalam proses belajar terjadi aktivitas siswa serta didapatkan hasil belajar setelah selesai proses belajar tersebut. Proses belajar mengajar adalah fenomena yang kompleks, dimana melibatkan setiap kata, pikiran, tindakan, dan juga asosiasi. Proses belajar yang berkulitas dan relevan tidak dapat terjadi dengan sendirinya, melainkan perlu direncanakan. Berkaitan dengan hal itu, maka guru merupakan komponen pertama dan utama yang sangat mempengaruhi kualitas proses belajar.

Belajar merupakan kegiatan aktif siswa (aktivitas belajar siswa) dalam membangun makna atau pemahaman, maka guru perlu memberikan dorongan kepada siswa dengan menggunakan otoritasnya dalam membangun gagasan (Ariswati, 2018; Chiang \& Lee, 2016; Suryawati et al., 2020). Tanggung jawab belajar memang berada pada diri siswa, tetapi guru tetap bertanggung jawab untuk menciptakan situasi yang mendorong prakarsa, motivasi, dan tanggung jawab siswa untuk belajar sepanjang hayat. Setiap siswa mempunyai cara yang optimal dalam mempelajari informasi tertentu. Beberapa siswa perlu diberikan cara-cara yang lain dari metode mengajar yang pada umumnya disajikan. Oleh karena itu guru agar dapat mengembangkan kreativitasnya untuk menciptakan gaya dan cara menyajikan bahan kajian tertentu, sehingga aktivitas belajar dan motivasi belajar siswa dapat ditingkatkan yang bermuara kepada peningkatan hasil belajar siswa.

Penelitian ini didukung dengan penelitian-penelitian sebelumnya yang relevan seperti: pertama penelitian yang dilaksanakan oleh (Juliawan et al., 2017), yang memperoleh hasil penelitian bahwa model problem based learning berpengaruh terhadap kemampuan pemecahan masalah. Kedua, penelitian yang dilaksanakan oleh (Febriana et al., 2020), yang memperoleh hasil penelitian bahwa modul pembelajaran berbasis problem based learning terbukti dapat meningkatkan kreativitas pemecahan masalah. Ketiga, penelitian yang dilaksanakan oleh (Winursiti, 2017), yang memperoleh hasil penelitian bahwa penerapan model problem based learning berbantuan reinforcement simbolik terbekti mampu meningkatkan motivasi dan hasil belajar siswa.

Tujuan dilaksanakannya penlitian ini adalah untuk menganalisis penerapan model pembelajaran problem-based learning (PBL) terhadap aktivitas dan hasil belajar PPKn siswa kelas X T0.1 SMK Negeri 2 Negara Tahun pelajaran 2019/2020.

\section{Metode}

Penelitian ini merupakan termasuk jenis penelitian tindakan kelas (PTK). Penelitian tindakan didasarkan pada filosofi bahwa setiap manusia tidak suka atas hal-hal yang statis, tetapi selalu menginginkan sesuatu yang lebih baik, peningkatan diri untuk hal yang lebih baik ini dilakukan terus menerus sampai tujuan tercapai (Dwicahyani et al., 2019; Kurniawan et al., 2018; Sulastri, 2020). Subjek penelitian ini adalah semua siswa kelas X T0.1 SMK Negeri 2 Negara Tahun pelajaran 2019/2020 yang terdiri dari 31 orang siswa. Objek dalam penelitian ini adalah peningkatan aktivitas belajar dan hasil belajar siswa kelas X T0.1 SMK Negeri 2 Negara setelah diterapkan model Problem Based Learning (PBL) dalam proses pembelajaran. Penelitian ini dilakukan dari bulan Juli sampai dengan bulan september. Teknik pengumpulan data pada penelitian ini menggunakan observasi dan tes hasil belajar. Data tentang aktifitas setiap aktivitas belajar siswa dilihat dengan menggunakan format observasi aktivitas siswa, kemudian ditabulasikan, apakah aktifitasnya meningkat atau tidak. Hasil data ini dapat dinyatakan dengan baik atau kurang baik.

Untuk memperoleh persentase aktivitas dan hasil belajar siswa, teknik analisis data yang yang digunakan adalah teknik analisis statistik deskriptif kuantitatif. Indikator keberhasilan penelitian tindakan ini adalah bila terjadi peningkatan aktifitas belajar dan hasil belajar siswa yang dihitung berdasarkan prosentase pada setiap siklusnya. Kriteria hasil belajar siswa menggunakan rata-rata tes ulangan harian. Sekurang-kurangnya siswa lulus secara klasikal sebanyak 75\%. Siswa lulus secara individual jika nilai yang diperoleh minimal 70 (sesuai kriteria ketuntasan minimal mata pelajaran PPKn SMK Negeri 2 Negara). Untuk keaktifan siswa dikatakan berhasil bila mencapai prosentase baik yaitu antara $61-80 \%$ dan sangat baik jika melebihi $80 \%$ siswa yang aktif. Dengan arti kata penelitian akan 
berhasil dan sangat baik jika ada peningkatan aktivitas belajar siswa mencapai $>80 \%$ setelah proses pembelajaran menggunakan model pembelajaran Problem Based Learning (PBL).

\section{Hasil dan Pembahasan}

Kegiatan pembelajaran dilakukan 2 siklus. Siklus 1 dilakukan selama dua kali pertemuan (empat jam pelajaran), pertemuan ke-1 dilakukan kegiatan pembelajaran dengan mengamati aktivitas siswa dan guru dalam pembelajaran menggunakan model pembelajaran Problem Based Learning(PBL) , sedangkan kegiatan tes hasil belajar dilakukan pada pertemuan ke-2 sekaligus melaksanakan pembahasan serta perencanaan kegiatan pada siklus 2. Hasil tindakan pada tiap siklus ditampilkan pada Tabel 1.

Tabel 1. Rekapitulasi Aktivitas Belajar Siswa Selama Proses Pembelajaran

\begin{tabular}{|c|c|c|c|c|c|c|}
\hline \multirow{3}{*}{ Aspek Aktivitas Belajar Siswa } & \multicolumn{6}{|c|}{ Jumlah Siswa } \\
\hline & \multicolumn{2}{|c|}{ Pra Siklus } & \multicolumn{2}{|c|}{ Siklus 1} & \multicolumn{2}{|c|}{ Siklus 2} \\
\hline & Jumlah & $\%$ & Jumlah & $\%$ & Jumlah & $\%$ \\
\hline Siswa Giat Memeriksa Materi & 17 & 54.84 & 20 & 64.52 & 31 & 100.00 \\
\hline $\begin{array}{l}\text { Siswa Menemukan Hal-Hal Penting } \\
\text { dari Materi }\end{array}$ & 13 & 41.94 & 19 & 61.29 & 27 & 87.10 \\
\hline $\begin{array}{l}\text { Siswa Menunjukkan Kemampuan } \\
\text { Analisis }\end{array}$ & 14 & 45.16 & 20 & 64.52 & 26 & 83.87 \\
\hline Siswa Kritis dalam Berpikir & 11 & 35.48 & 19 & 61.29 & 23 & 74.19 \\
\hline $\begin{array}{l}\text { Kemampuan Memecahkan Masalah } \\
\text { Lewat Masalah }\end{array}$ & 15 & 48.39 & 18 & 58.06 & 27 & 87.10 \\
\hline $\begin{array}{l}\text { Siswa Cepat Menanggapi Tuntutan } \\
\text { Siswa Menunjukkan Kemampuan }\end{array}$ & 10 & 32.26 & 17 & 54.84 & 23 & 74.19 \\
\hline $\begin{array}{l}\text { Lebih Memproses } \\
\text { Sesuatu yang Bermakna }\end{array}$ & 9 & 29.03 & 14 & 45.16 & 25 & 80.65 \\
\hline $\begin{array}{l}\text { Pembelajaran Berpusat pada Diri } \\
\text { Siswa }\end{array}$ & 17 & 54.84 & 23 & 74.19 & 31 & 100.00 \\
\hline $\begin{array}{l}\text { Siswa Mampu Menelorkan } \\
\text { Kesimpulan-Kesimpulan }\end{array}$ & 18 & 58.06 & 25 & 80.65 & 31 & 100.00 \\
\hline Jumlah & & 400.00 & & 564.52 & & 787.10 \\
\hline Rata-Rata & & 44.44 & & 62.72 & & 87.46 \\
\hline
\end{tabular}

Dari data pada Tabel 1 diatas, diperoleh dari pelaksanaan observasi oleh pengamat terhadap aktivitas belajar siswa dengan mempergunakan model pembelajaran Problem Based Learning(PBL) dapat diketahui apakah aktivitas siswa rendah, cukup, tinggi atau tinggi sehingga dapat diketahui peningkatan aktivitas yang diharapkan. Aktivitas siswa pada Tabel dapat diukur secara kualitatif dan kuantitatif.

Berdasarkan pedoman konversi aktivitas belajar siswa, maka dapat ditarik suatu kesimpulan bahwa siswa telah menampakkan peningkatan aktivitas belajar dari rerata pada pra siklus 44,44 (Cukup) ke siklus 1 rerata 62,72 (Baik) maupun ke siklus 2 rerata 87,46 (Amat Baik). Dengan tingkat kehadiran siswa $100 \%$.

Selain aktivitas secara Individu. Dalam pelaksanaaan pembelajaran juga diamati aktivitas siswa secara kelompok, Adapun hasil pengamatan aktivitas siswa secara kelompok ditampilkan pada Tabel 2.

Tabel 2. Prosentase Kenaikan Kinerja pada Tiap Kelompok

\begin{tabular}{ccccccc}
\hline No. & Nama Kelompok & Pra Siklus & Siklus 1 & Siklus 2 & \% Pra Siklus ke 1 & \% Siklus 1 ke 2 \\
\hline 1 & $\mathrm{~A}$ & 68.00 & 76.00 & 88.00 & $11.85 \%$ & $16.33 \%$ \\
2 & $\mathrm{~B}$ & 66.00 & 74.00 & 84.00 & $11.85 \%$ & $13.61 \%$ \\
3 & $\mathrm{C}$ & 72.00 & 76.00 & 90.00 & $5.93 \%$ & $19.05 \%$ \\
4 & $\mathrm{D}$ & 64.00 & 68.00 & 84.00 & $5.93 \%$ & $21.77 \%$ \\
\hline & Rata-Rata & $\mathbf{6 7 . 5 0}$ & $\mathbf{7 3 . 5 0}$ & $\mathbf{8 6 . 5 0}$ & $\mathbf{8 . 8 9 \%}$ & $\mathbf{1 7 . 6 9 \%}$ \\
\hline
\end{tabular}

Dari Tabel 2, diperoleh bahwa rata-rata prosentase kinerja kelompok terdapat kenaikan. Ini berarti bahwa model pembelajaran Problem Based Learning (PBL) mampu memberikan kontribusi kepada siswa dalam proses pembelajaran secara signifikan. Di samping itu, kenaikan antar siklusnya juga 
mengalami peningkatan yaitu dari pra Siklus ke Siklus 1 naik 8,89\% menjadi $17.69 \%$ dari Siklus 1 ke Siklus 2. Dimana tingkat kehadiran siswa selama proses pembelajaran adalah $100 \%$.

Dari data diatas, terlihat kenaikan aktivitas belajar siswa secara individu pada tiap aktivitas yang diamati. Penelitian ini dilakukan kedalam beberapa aktivitas, yaitu: (1) aktivitas pertama, jumlah siswa yang giat memeriksa materi pembelajaran pada pra siklus ada 17 orang $(54,84 \%)$, pada siklus 1 naik menjadi 20 orang $(64,52 \%)$, sedangkan pada siklus 2 naik lagi menjadi 31 orang (100\%); (2) aktivitas kedua, jumlah siswa yang menemukan hal-hal penting dari materi pembelajaran pada pra siklus ada 13 orang $(41,94 \%)$, pada siklus 1 naik menjadi 19 orang $(61,29)$, sedangkan pada siklus 2 naik lagi menjadi 27 orang (87,10\%); (3) aktifitas ketiga, jumlah siswa yang menunjukkan kemampuan analisis pada pra siklus ada 14 orang $(45,16 \%)$, pada siklus 1 naik menjadi 20 orang $(64,52 \%)$, sedangkan pada siklus 2 naik lagi menjadi 26 orang (92,86\%); (4) aktivitas keempat, jumlah siswa kritis dalam berpikir pada pra siklus ada 11 orang $(35,48 \%)$, pada siklus 1 naik menjadi 19 orang $(61,29 \%)$, sedangkan pada siklus 2 naik lagi menjadi 23 orang (74,19\%); (5) aktivitas kelima, jumlah siswa memecahkan masalah lewat masalah pada pra siklus ada 15 orang (48,39\%), pada siklus 1 naik menjadi 18 orang $(58,06 \%)$, sedangkan pada siklus 2 naik lagi menjadi 27 orang (87,10\%); (6) aktivitas keenam, jumlah siswa cepat menanggapi tuntutan pada pra siklus ada 10 orang (32,26\%), pada siklus 1 naik menjadi 17 orang (54,84\%), sedangkan pada siklus 2 naik lagi menjadi 23 orang (74,19\%); (7) aktivitas ketujuh, jumlah siswa menunjukkan kemampuan lebih memproses sesuatu yang bermakna pada pra siklus ada 9 orang (29,03\%), pada siklus 1 naik menjadi 14 orang $(45,16 \%)$, sedangkan pada siklus II naik lagi menjadi 25 orang (80,65\%); (8) aktivitas kedelapan, jumlah siswa Pembelajaran Berpusat Pada Diri Siswa pada pra siklus ada 17 orang $(54,84 \%)$, pada siklus 1 naik menjadi 23 orang $(74,19 \%)$, sedangkan pada siklus 2 naik lagi menjadi 31 orang (100,00\%); (9) aktivitas kesembilan, jumlah siswa menelorkan kesimpulankesimpulan pada pra siklus ada 18 orang $(58,06 \%)$, pada siklus 1 naik menjadi 25 orang $(80,65 \%)$, sedangkan pada siklus 2 naik lagi menjadi 31 orang $(100,00 \%)$.

Setelah memperoleh hasil kesembilan aktivitas tersebut, maka dilanjutkan dengan mnganalisis hasil belajar siswa. Tes hasil belajar dilakukan pada pertemuan ke-2 sekaligus melaksanakan pembahasan serta perencanaan kegiatan pada siklus 2. Hasil belajar dari tindakan pada tiap siklus ditampilkan pada Tabel 3.

Tabel 3. Rekapitulasi Hasil Belajar Siswa pada Pra Siklus, Siklus 1, dan Siklus 2

\begin{tabular}{cccccc}
\hline \multirow{2}{*}{ No. } & \multirow{2}{*}{ Tes Tiap Siklus } & \multicolumn{2}{c}{ Tuntas } & \multicolumn{2}{c}{ Belum Tuntas } \\
\cline { 3 - 5 } & & Jumlah & \% & Jumlah & \% \\
\hline 1 & Pra Siklus & 9 & $29.03 \%$ & 22 & $70.97 \%$ \\
2 & Siklus 1 & 23 & $74.19 \%$ & 8 & $25.81 \%$ \\
3 & Siklus 2 & 29 & $93.55 \%$ & 2 & $6.45 \%$ \\
\hline
\end{tabular}

Dari Tabel 3 terlihat adanya peningkatan hasil belajar PPKn pada materi Kewenangan Lembagalembaga Negara, siswa kelas X T0.1 SMK Negeri 2 Negara. Dengan jumlah 31 orang siswa yaitu sebagai berikut: pada pra siklus jumlah siswa yang tuntas adalah 9 orang, dan 22 orang lainnya dinyatakan belum tuntas karena belum mencapai nilai 75 (sesuai dengan KKM). Sedangkan pada siklus 1 terdapat 23 siswa yang tuntas belajar dan 8 siswa yang belum tuntas. Pada siklus 2 jumlah siswa yang tuntas naik mencapai 29 orang dan 2 lainnya belum tuntas. Dengan tingkat kehadiran siswa saat mengikut tes adalah $100 \%$. Karena jumlah siswa yang tuntas melebihi $75 \%$, maka penelitian tindkaan kelas yang dilakukan guru sudah berhasil. Artinya penggunaan model pembelajaran Problem Based Learning (PBL) dalam melaksanakan pembelajaran mata pelajaran PPKn terbukti dapat meningkatkan hasil belajar siswa.

Model sangat berkaitan dengan teori, model merupakan suatu analog konseptual yang digunakan untuk menyarankan bagaimana meneruskan penelitian empiris sebaiknya tentang suatu masalah. Jadi model merupakan suatu struktur konseptual yang telah berhasil dikembangkan dalam suatu bidang dan sekarang diterapkan, terutama untuk membimbing penelitian dan berpikir dalam bidang lain, biasanya dalam bidang yang belum begitu berkembang (Istiandaru et al., 2015; Juliawan et al., 2017; Wajdi, 2017).

Model pembelajaran problem based learning (pembelajaran berbasis masalah), awalnya dirancang untuk program graduate bidang kesehatan oleh Barrows, Howard yang kemudian diadaptasi dalam bidang pendidikan oleh Gallagher (Fitri et al., 2020; Ratnawati et al., 2020; Tomas \& Prasetyo, 2020). Kelebihan model pemblajaran problem based learning (PBL) disetting dalam bentuk pembelajaran yang diawali dengan sebuah masalah dengan menggunakan instruktur sebagai pelatihan metakognitif dan diakhiri dengan penyajian dan analisis kerja siswa, dengan aktivitas tersebut dapat memotivasi siswa untuk mengikuti kegiatan pembelajaran dengan baik (Pratiwi \& Setyaningtyas, 2020; Sucipto, 2017; Suhendar \& Ekayanti, 2018). 
Penelitian ini didukung dengan penelitian-penelitian sebelumnya yang relevan seperti: pertama penelitian yang dilaksanakan oleh (Juliawan et al., 2017), yang memperoleh hasil penelitian bahwa model problem based learning berpengaruh terhadap kemampuan pemecahan masalah. Kedua, penelitian yang dilaksanakan oleh (Febriana et al., 2020), yang memperoleh hasil penelitian bahwa modul pembelajaran berbasis problem based learning terbukti dapat meningkatkan kreativitas pemecahan masalah. Ketiga, penelitian yang dilaksanakan oleh (Winursiti, 2017), yang memperoleh hasil penelitian bahwa penerapan model problem based learning berbantuan reinforcement simbolik terbekti mampu meningkatkan motivasi dan hasil belajar siswa.

Implikasi dari pelaksanaan penelitian tindakan kelas (PTK) ini adalah penerapan model pembelajaran problem-based learning (pembelajaran berbasis masalah) dapat memotivasi siswa untuk belajar dan menambah pengalaman baru bagi siswa.

\section{Simpulan}

Berdasarkan analisis Hasil dan pembahasan, maka dapat ditarik kesimpulan bahwa penerapan model pembelajaran PBL terbukti dapat meningkatkan aktivitas dan hasil belajar PPKn siswa. Implikasi dari penelitian ini adalah penerapan model pembelajaran PBL dapat memotivasi siswa untuk belajar dan menambah pengalaman baru bagi siswa.

\section{Daftar Rujukan}

Abdurrozak, R., \& Jayadinata, A. K. (2016). Pengaruh Model Problem Based Learning Terhadap Kemampuan Berpikir Kreatif Siswa. Jurnal Pena Ilmiah, 1(1), 871-880. https://doi.org/10.23819/pi.v1i1.3580

Alkhasawneh, I. M., Mrayyan, M. T., Docherty, C., Alashram, S., \& Yousef, H. Y. (2008). Problem-based learning (PBL): Assessing students' learning preferences using vark. Nurse Education Today, 28(5), 572-579. https://doi.org/10.1016/j.nedt.2007.09.012

Amelia, D. J., \& Saputra, S. Y. (2017). Analisis Kelayakan Buku Siswa Kelas IV Tema Makhluk Hidup Kurikulum 2013. Pedagogia: Jurnal Pendidikan, 6(1), 98-109. https://doi.org/10.21070/pedagogia.v6i1.617

Ariswati, N. P. E. A. (2018). Pengaruh Model Pembelajaran Problem Based Learning Terhadap Hasil Belajar Matematika Siswa Kelas V Sd Negeri Nanggulan. Mimbar PGSD, 6(4). https://doi.org/10.1590/s1809-98232013000400007

Ariyanti, M. (2017). Perbandingan keefektifan model project-based learning dan problem-based learning ditinjau dari ketercapaian tujuan pembelajaran. Jurnal Pendidikan Matematika Dan Sains, 5(1), 1 10. https://doi.org/https://doi.org/10.21831/jpms.v5i1.13469

Chiang, C. L., \& Lee, H. (2016). The Effect of Project-Based Learning on Learning Motivation and ProblemSolving Ability of Vocational High School Students. International Journal of Information and Education Technology, 6(9), 709-712. http://www.ijiet.org/show-76-881-1.html

Christiana, P. P., Suniasih, N. W., \& Suadnyana, I. N. (2014). Pengaruh Model Problem Based Learning Berbasis Penilaian Proyek terhadap Kemampuan Berpikir Kritis IPA SD Gugus VIII Sukawati. EJournal Mimbar PGSD Universitas Pendidikan Ganesha, 2(1). https://doi.org/10.23887/jjpgsd.v2i1.2031

Dwicahyani, N. M., Wiarta, I. W., \& Ardana, I. K. (2019). Penerapan Model Pembelajaran Nht Berbantuan Media Gambar Meningkatkan Penguasaan Kompetensi Ips. Journal for Lesson and Learning Studies, 2(1), 102-110. https://doi.org/10.23887/jlls.v2i1.17326

Farah, M., Saminan., \& Zainal, A. (2020). The implementation of problem-based learning (PBL) model to improve creativity and self-efficacy of field dependent and field independent students. Malikussaleh Journal of Mathematics Learning, 3(1), 13-17. https://doi.org/10.29103/mjml.v3i1.2402

Febriana, R., Yusri, R., \& Delyana, H. (2020). Modul Geometri Ruang Berbasis Problem Based Learning Terhadap Kreativitas Pemecahan Masalah. Aksioma: Jurnal Program Studi Pendidikan Matematika, 9(1), 93. https://doi.org/10.24127/ajpm.v9i1.2591

Fitri, M., Yuanita, P., \& Maimunah, M. (2020). Pengembangan Perangkat Pembelajaran Matematika 
Terintegrasi Keterampilan Abad 21 Melalui Penerapan Model Problem Based Learning (PBL). Jurnal Gantang, 5(1), 77-85. https://doi.org/10.31629/jg.v5i1.1609

Han, S., \& Rosli, R. (2016). The Effect of Science, Technology, Engineering and Mathematics ( STEM) Project Based Learning ( PBL ) on Students ' Achievement in Four Mathematics Topics. Journal of Turkish Science Education, 13, 3-29. https://doi.org/10.12973/tused.10168a

Herzon, H. H., Budijanto, \& Utomo, D. H. (2018). Pengaruh Problem-Based Learning (PBL) terhadap Keterampilan Berpikir Kritis. Jurnal Pendidikan: Teori, Penelitian, Dan Pengembangan, 3(1), 4246. http://journal.um.ac.id/index.php/jptpp/

Indriani, A. (2015). Penerapan Pembelajaran Tematik Kurikulum 2013 oleh Guru SD/MI di Desa Klepek Kecamatan Sukosewu Kabupaten Bojonegoro Semester Gasal Tahun Ajaran 2014/2015. Jurnal VARIDIKA, 27(1), 43-49. https://doi.org/10.23917/varidika.v27i1.738

Istiandaru, A., Istihapsari, V., Wardono, \& Mulyono. (2015). Problem Based Learning (PBL) dengan Pendekatan Realistik-Saintifik dan Asesmen PISA untuk Meningkatkan Kemampuan Literasi Matematika. Edumatica, 5(1), 1-11. https://doi.org/10.22437/edumatica.v5i01.2670

Juliawan, G. A., Mahadewi, L. P. P., \& Rati, W. R. (2017). Pengaruh Model Problem Based Learning (PBL) Terhadap Kemampuan Pemecahan Masalah Matematika. Mimbar PGSD, 5(2), 1-10. https://doi.org/10.23887/jjpgsd.v5i2.10881

Khofiatun, Akbar, S., \& Ramli, M. (2016). Peran Kompetensi Pedagogik Guru Dalam Pembelajaran Tematik Di Sekolah Dasar. Jurnal Pendidikan, 1(5), 984-988. https://doi.org/10.17977/jp.v1i5.6336

Krissandi, A. D. S., \& Rusmawan, R. (2015). Kendala Guru Sekolah Dasar Dalam Implementasi Kurikulum 2013. Jurnal Cakrawala Pendidikan, 3(3), 457-467. https://doi.org/10.21831/cp.v3i3.7409

Kurniaman, O., \& Noviana, E. (2017). Penerapan Kurikulum 2013 Dalam Meningkatkan Keterampilan, Sikap, Dan Pengetahuan. Primary: Jurnal Pendidikan Guru Sekolah Dasar, 6(2). https://doi.org/10.33578/jpfkip.v6i2.4520

Kurniawan, H. R., Elmunsyah, H., \& Muladi. (2018). Perbandingan Penerapan Model Pembelajaran Project Based Learning Dan Think Pair Share Berbantuan Modul Ajar Terhadap Kemandirian Dan Hasil Belajar Siswa Kelas XI di SMKN 3. Jurnal Pendidikan (Teori Dan Praktik), 3(2), 80-85. https://doi.org/10.26740/jp.v3n2.p80-85

Larasati, V., \& Gafur, A. (2018). Hubungan kompetensi pedagogis dan kompetensi profesional guru PPKn dengan prestasi belajar siswa sekolah menengah. Jurnal Civics: Media Kajian Kewarganegaraan, 15(1), 45-51. https://doi.org/10.21831/jc.v15i1.17282

Maiza, Z., \& Nurhafizah, N. (2019). Pengembangan Keprofesian Berkelanjutan dalam Meningkatkan Profesionalisme Guru Pendidikan Anak Usia Dini. Jurnal Obsesi : Jurnal Pendidikan Anak Usia Dini, 3(2), 356-365. https://doi.org/10.31004/obsesi.v3i2.196

Maryatun, \& Metro, P. E. F. U. M. (2017). Pengaruh Penggunaan Model Problem Based Learning (PBL) Terhadap Hasil Belajar Ekonomi Siswa Kelas X Semester Genap Sma Pgri 1 Metro Tahun Pelajaran 2016/2017. Jurnal Pendidikan EKonomi, 5(1), 152-159. https://doi.org/10.24127/ja.v5i2.1225

Mediatati, N. (2017). Meningkatkan Hasil Belajar PPKn Menggunakan Model Pembelajaran Examples Non Examples pada Siswa. Journal of Education Research and Evaluation, 1(2), 100. https://doi.org/10.23887/jere.v1i2.10073

Nuryana, N., \& Sahrir, D. C. (2020). Pelatihan Kurikulum 2013 Edisi Revisi 2018 bagi Guru di Yayasan Pendidikan Islam Al-Maunah. Jurnal Pengabdian Pada Masyarakat, 5(1), 1 - 10. https://doi.org/10.30653/002.202051.259

Pratiwi, E. T., \& Setyaningtyas, E. W. (2020). Kemampuan Berpikir Kritis Siswa SD dengan Model Pembelajaran Problem Based Learning dan Model Pembelajaran Project Based Learning. Jurnal Basicedu, 4(2), 379-388. https://doi.org/10.31004/basicedu.v4i4.445

Ramlawati, Yunus, S. R., \& Insani, A. (2017). Pengaruh Model PBL (Problem Based Learning) terhadap Motivasi dan Hasil Belajar IPA Peserta Didik. Jurnal Sainsmat, 6(1), 1-14. https://ojs.unm.ac.id/sainsmat/article/view/6451 
Ratnawati, D., Handayani, I., \& Hadi, W. (2020). Pengaruh Model Pembelajaran Pbl Berbantu Question Card Terhadap Kemampuan Berpikir Kritis Matematis Siswa SMP. Edumatica : Jurnal Pendidikan Matematika, 10(01), 44-51. https://doi.org/10.22437/edumatica.v10i01.7683

Rerung, N., Sinon, I. L. ., \& Widyaningsih, S. W. (2017). Penerapan Model Pembelajaran Problem Based Learning (PBL) untuk Meningkatkan Hasil Belajar Peserta Didik SMA pada Materi Usaha dan Energi. Jurnal Ilmiah Pendidikan Fisika Al-Biruni, 6(1), 47-55. https://doi.org/10.24042/jpifalbiruni.v6i1.597

Sanistyasari, I. G. A. N. (2019). Pengaruh Metode Karyaswasta Fantasi Di Lingkungan Sekolah Berbantuan Majalah Dinding Terhadap Kompetensi Pengetahuan PPKn. Jurnal Pendidikan IPS Indonesia, 3(1), 21-31. https://doi.org/10.23887/pips.v3i1.2874

Sucipto, S. (2017). Pengembangan Ketrampilan Berpikir Tingkat Tinggi Dengan Using Pengembangan Strategi Model Metakognitif Pembelajaran Problem Based Learning. Jurnal Pendidikan (Teori Dan Praktik), 2(1), 63-71. https://doi.org/10.26740/jp.v2n1.p77.

Suhendar, U., \& Ekayanti, A. (2018). Problem based learning sebagai upaya peningkatan konsep matematis mahasiswa. Jurnal Dimensi Pendidikan Dan Pembelajaran, 6(1), 16-19. https://doi.org/10.24269/dpp.v6i1.815

Sulastri, S. (2020). Peningkatan Kemandirian Belajar IPA dengan Penerapan Model Pembelajaran Numbered Heads Together pada Siswa Kelas V SDN 43 Rejang Lebong. PENDIPA Journal of Science Education, 4(3), 46-51. https://doi.org/10.33369/pendipa.4.3.46-51

Sumarni, W., Wardani, S., \& Gupitasari, D. N. (2016). Project Based Learning (PBL) To Improve Psychomotoric Skills : A Classroom Action Research. Jurnal Pendidikan IPA Indonesia, 5(2), 157163. https://doi.org/10.15294/jpii.v5i2.4402

Suryawati, E., Suzanti, F., Zulfarina, Putriana, A. R., \& Febrianti, L. (2020). The implementation of local environmental problem-based learning student worksheets to strengthen environmental literacy. Jurnal Pendidikan IPA Indonesia, 9(2), 169-178. https://doi.org/10.15294/jpii.v9i2.22892

Tomas, \& Prasetyo, T. (2020). Pengaruh Penggunaan Model Problem Based Learning (Pbl) Terhadap Motivasi Belajar Matematika Pada Siswa Kelas 4 Sd. JPPGuseda / Jurnal Pendidikan \& Pengajaran Guru Sekolah Dasar, 3(1), 13-18. https://doi.org/10.33751/jppguseda.v3i1.1919

Wahyudin, W. (2018). Optimalisasi Peran Kepala Sekolah dalam Implementasi Kurikulum 2013. Jurnal Kependidikan, 6(2), 249-265. https: //doi.org/10.24090/jk.v6i2.1932

Wajdi, F. (2017). Implementasi Project Based Learning (PBL) Dan Penilaian Autentik Dalam Pembelajaran Drama Indonesia. Jurnal Pendidikan Bahasa Dan Sastra, 17(1), 81-97. https://doi.org/10.17509/bs_jpbsp.v17i1.6960

Winursiti, N. M. (2017). Penerapan Model Problem Based Learning Berbantuan Reinforcement Simbolik untuk Meningkatkan Motivasi dan Hasil Belajar Matematika Siswa Kelas IVB Semester I Tahun Pelajaran 2017/2018 di SD LAB Undiksha. Jurnal Ilmiah Sekolah Dasar, 1(4), 270-275. https://doi.org/http://dx.doi.org/10.23887/jisd.v1i4.12120 